\title{
Investigating Effective Factors on Development of Tourism Industry in Iran
}

\author{
Seyed Fathollah Amiri Aghdaie (Corresponding author) \\ Assistant Professor, Dep. of Management, University of Isfahan, Isfahan, Iran \\ Tel: 98-311-793-5251Ｅ-mail: Aghdaie@mang.ui.ac.ir \\ Ramin Momeni \\ M.S Student, Dep. of Management, University of Isfahan, Isfahan, Iran \\ Tel: 98-711-823-9098Ｅ-mail: R.momeni@mehr.ui.ac.ir
}

Received: May 23, $2011 \quad$ Accepted: June 30, $2011 \quad$ Published: December 1, 2011

doi:10.5539/ass.v7n12p98

URL: http://dx.doi.org/10.5539/ass.v7n12p98

\begin{abstract}
Since long times ago, depending on petroleum and its products has been the most important challenge in Iran's economy. Therefore reducing the role of that and substituting it with other industries is one of the principal purposes of Iran's economic projects. Among these substituting industries, tourism is the most important one. Because of creating many job opportunities, entering lots of foreign exchange and has the minimum environmental pollution. However in Iran does not given priority to tourism industry as it deserves, so Iran which is the $5^{\text {th }}$ attractive country in the world, in 2009 was place $137^{\text {th }}$ ranking of the countries in terms of attracting tourists. Therefore, it seems absolutely necessary to take tourism industry into consideration more seriously.

The goal of this study is investigating the effective factors on tourism industry in Iran, the mentioned goal will be accomplished by variable factors such as advertisement and informing people, tourist's safety and security, reducing tourism expense, increasing welfare services and its quality, increasing foreign investment and expanding foreign relation as research hypothesis. The type of article is descriptive-cognitive and the related information for this scope has been collected by using library resources and moreover for collecting necessary data in order to accept or reject the research hypothesis a questionnaire made by researchers has been used. Statistical society for this research includes the managers of tourism agencies in Isfahan city and the method being used has been random sampling. All the variables have positive effect on tourism industry in Iran.
\end{abstract}

Keywords: Tourism industry, Risk, Advertising, Welfare services, Tourism attraction

\section{Introduction}

Tourism is one of the most profitable businesses of the world. This industry now is considered as a leading industry in many countries due to faster growth than other sectors of the economy and creates numerous job opportunities. Tourism today is so important in the economic and social development of countries, and economists have called it as invisible exports. In division of the most important sources of income in the world, oil exploration and exploitation industry is considered as the highest income industrial activity, the automotive industry comes after that, and tourism is the third. Increasing number of tourists in the world from 25 million people in 1950 to 922 millions in 2008 and its average annual growth of 5.6 percent shows the economic importance of the tourism industry more than ever, therefore $10 \%$ of GDP and $10 \%$ of world employment is now allocated to tourism industry (UNWTO, 2010). Economic thinkers today believe that the developing countries are more interest to develop their tourism industry. These countries consistently followed up the industries that have high job creation, and provide their needed foreign currency. Therefore, they are trying to use the modern facilities to develop the tourism industry based on international standards, whereupon in addition to increase employment and providing foreign exchange, they also provide economic prosperity of their country. 
Iran is a country with high potential to attract tourists. in terms of security, Iran has an excellent position in the world, a country with four various seasons, with very high climate variability, the fifth country holds natural attractions, the tenth historical country of the world, and with 12 recorded archaeological works by UNESCO. Persepolis, Tchogha Zanbil, Takht-e Soleyman, Pasargadae, Meidan Emam Isfahan, Bam and its Cultural Landscape, bisotun, Shushtar Historical Hydraulic System, Soltaniyeh, Armenian Monastic Ensembles of Iran, Sheikh Safi al-din and Shrine Ensemble in Ardabil and Tabriz Historic Bazaar Complex are recorded as Iran's ancient sites (UNESCO, 2010). In addition, rich cultural mixture and a great civilization with historical and natural attractions, has been introduced Iran as an attractive country for tourists around of the world. However unfortunately, Iran's share of world tourism income is very low and is about 1\% (UNWTO, 2010).

Although in recent years, well attempts has been done including to hold national celebrations like norooz (new year) in neighboring countries and some European countries by the embassy of Islamic republic of Iran, creating a satellite network in English, and active participation in the tourism fairs. However, these measures are minimal against high capacities of Iran. Therefore it is necessary to identify obstacles and problems facing the industry. Also, the factors that most influence on its development be fully considered to provide well field for its grow and expand.

\section{Tourism industry}

Tourism refers to a set of activities, interaction and communication between tourists and countries which are hosts and responsible to prepare all the needs of tourists, including accommodation, transportation, foods, funs, security and other necessary things and a tourists is a person who wants to spend his time in another city, province or country for recreation, business, study or other purposes. Tourism words for the first time in 1937 officially were used by the nations union but the tourism industry has a very long history (Gharanejad, 2007).

In Iran, tourism has boom since long time ago, western historians and tourists traveling, existence of old caravansaries between the ways, and widespread communication road, are the evidence of this claims. One of the brilliant eras of tourism industry in Iran was the time of Safavi's kingdom that increased internal security, development and welfare of roads and architectural blossoming of Iranian were the most important factors in attracting foreign tourists at that time. In 1935 for the first time in Iran established an office which called office of attracts foreign tourist and advertising administration and affairs related to the tourism were its responsibility. In 1978 with the victory of Islamic revolution, ministry of information and tourism were created and later its name changed to ministry of culture and Islamic guidance.

In 1971 Iran and a foreign company called Tourist Consult signed an agreement in order to study regarding different aspects of tourism industry such as policies, advantages and facilities. In fact this was the start of the blossoming of tourism in Iran before the Islamic revolution. From this date onwards the country has witnessed the development of the industry, and acceptable rate of tourists entering has increased. For example in 1978 only seven years after the above contract the number of tourists in comparison with the year of 1969 which were 241,198 tourists, increased to 502,278 , and this is almost more than $100 \%$ increase(Iran cultural heritage organization, 2009). After the Islamic revolution, different political and security events, and also the war between Iran and Iraq disconnected, former growing trend and decreased tourism development indicators and caused a severe drop in international tourist's arrival. Lack of growth and development of the Iran tourism industry continued until 2006, but after this year through special attention of the government we could see more tourists coming to Iran.

Now, after passing about two centuries from the appearance of tourism, this industry has been considered more than any other time. Tourism industry is a pioneer factor in economy that in addition to creates job opportunity and provide foreign exchanges, it is also causes to increases the power of production in countries. In fact, due to existence of economical activities related to tourism, increasing the demand of tourism causes the increase of different demands for some others products and services, and finally the result of that, increased the production capacity of society.

Although Iran has achieved to some progresses in this industry but still has a long way to reach its suitable place in international arena. Therefore needs to improve and expand fundamental aspect of its tourism industry and attract more foreign tourists, addition to above matter also needs to modify in issuing visas, expands international relationships, extensive advertising for introduce more Iran to other nations and increasing the quality of welfare services. The following table shows Iran's revenue from tourism industry which is quite low (Table 1). 


\section{Risk}

The concept of risk refers to the threat which is from any event or action, and strongly affects the ability of an organization or industry in reaching its target (Mazloumi, 2007). Low risk and internal safety are the essential factors that tourists think over that and choose their destination on this basis. In fact tourists travel to countries where, there is no risk for their life and their money. Statistics issued by Iran's tourism office shows that majority of incoming tourists to Iran are cultural tourists who want to see cultural regions and historical places and they strongly avoid risk.

As terrorist activities, like war, human trafficking and drugs are considered a major threat for tourists, natural disasters like earthquakes, hurricanes, floods and infectious diseases also have strong impact on reducing the security of region and make the tourism industry of different areas in the world with recession. SARS outbreak in china in 2002, tsunami happened in the coast of Indonesia in 2004 and Katrina hurricane on August $29^{\text {th }}, 2005$ in America, are such cases that reduced the demand of tourism in those areas. The following table represents homicide and crime rates in different regions of the world and shows well the correlation between security and tourism (table, 2).

West, central and southeast of Europe and east, Southeast and Northeast of Asia with having about $65.5 \%$ of international tourists are the most secure parts of the world and versus, Africa with central and south of America with having only $8 \%$ of international tourists are the most insecure parts of the world (Tourism highlights, 2009). Another factor that could threaten the security of tourists in the country is poverty and economic problems of their people. Because wherever there is poverty, there are theft and kidnapping. In other words theft and robbery are the results of poverty.

On the other hand due to the tourists who are not familiar with the culture and relations between people in destination, they may be abused and extorted by swindlers. So the authorities of the countries are responsible to enhance safety of tourists, in order to stop bad events for them so they leave the country with sweet memories. Transportation is also one of the issues that make so much danger for tourists because the toll road accidents are one of the main causes of death in many countries. Using of safe and secure transportation, taking advantage of experienced and committed drivers, improving the country's roads and observing traffic laws are solutions that can reduce traffic accidents and strengthen the sense of safety and comfort in tourists.

Fortunately, in above indicators Iran is on favorite condition. By having a crime rate of 2.9 for homicide, Iran is one of the safest countries of the world. But the main problem in context of attracting is the lack of Iran's advertisement and other countries negative advertisement against Iran, and maybe that's why most of tourists who are leaving Iran declare that Iran is quite different with their image that they had before the trip, in their mind.

According to the above subjects, although Iran in terms of security and social internal is in good place, but for tourist's safety and their protection, it should do more supporting activities to consider interest of tourist more than before. Training skilled manpower that are familiar with international language, creating tourism police, using GPS (Global positioning System) tracking systems for the positioning of tourists are activities which have been done in developed counties and it can also be used as a model for Iran.

\section{Advertising}

Advertising and informing are very important factors in tourism industry, because tourism product and services are not portable and cannot import them to the country in order to use, therefore just by advertising information can be introduced to various countries and revealed their characteristic and features. In fact advertising is only the tool that can fill the gap between supply and demand in this industry. Today, developed countries use large scale advertising tools to attract more tourists. Advertising brochures, TV and internet advertising, tourism satellite networks and movies are case that increasingly used them for introducing natural and historical attractions of the countries. These countries provide abundant funds and facilities to professional directors and experts advertisements to use sounds and pictures in order to depict their countries in desirable and attractive form for the people of around the world.

Tourists need to correct, adequate and enough updated information in order to choose their destination because this decisions are base on information, therefore this is the duty of advertising sector that introduce all the natural and historical attractions of country and gives enough and necessary information to the tourists, but the things which is very important is giving the right information to them, because if they travel to a country and realized that they have given them incorrect data they would become deceived, so they think negative about the whole society, culture and the mentality of people and never again travel there, beside they might make negative 
propaganda against the country, so the others also discourage to travel. Advertising is closely linked with the science of psychology because research has shown that peoples model motivation, expectation, mental status and family background impact on how they spend their holidays (Les Lumsdon, 1997).

Therefore it is necessary that the advertising activities consider the expectation of all the society and attract the various tastes toward tourism industry. Another important and challenging issue that affects the travel and tourism is the pattern of people's traveling. Pattern of traveling refers to kind of their travel such as people who travel for surveillance historical and nature attractions, business, studies and etc. The best tool to determine travel patterns of people is categories of market segmentations of tourists. Market segmentations refer to the process which organization and companies classify their customers with considering their needs, whishes, and personality characteristics (McDonalds and Dumber, 1995). This act expects that makes separate the target markets also will targeted all the advertising activities and controls its expenditures. Because with focusing on the needs and personality characteristics of each group helps us to use suitable advertising for each group.

Methods of informing and advertising have many changes in recent years, in the old model tourism agencies and travel guide tours where interface between tourists and tourism products, in fact if a tourist needs to any information regarding a product or how and where he can find or buy they where the one who help him /her but now tourists with using internet directly and without intermediary can achieve to all the information's and services, addition to this their expenditure also reduced (Dimitrios and Laws, 2002 ) (Figure 1).

\section{Welfare services}

The most important specification of the tourism industry is that the products of this industry are more in the realm of the services. In other words, aviation companies, hotels, restaurants and the entire active organizations in the tourism industry, all are service firms performing activities as intermediate between production organizations and tourists. Recreational touring is the largest global tourism market that recreation, amusement, fun are the most important objective of this type of tourism. As recreation and amusement are not possible without welfare services such as proper hotels and restaurants and secure transportation system, so expanding the welfare services play an effective part in the development of the tourism industry. On the other hand, today people due to high knowledge and insight in access to their needs act with complete scrutiny and investigation, they are always comparing different services and products to choose best quality with cheapest price. Therefore besides expanding the welfare services, increasing the quality and offering the services by cheaper price lead to more attracting of tourists to a region and booming its tourism industry.

One of the important challenges of tourism services is the difference of the quality standards of the services in different times. In fact, we cannot expect fully similar services offered in different times. As an example, an aviation company that was satisfactory traveling by it for the client in the past, may suffer him in the next travel in the aircraft faces with the air wells, so this affects negatively on his next choices, or a beautiful coast that has attracted the tourists in past, an unfavorable climate at the next visit lead to changing of the mentality of him and demolishing the feature of destination. Another important issue is that, although tourism products are sold wholly, they are not in fact one single product, but they are combination of various products that may each being at a different quality level. So the same reason a low quality a product causes the decrease of other service value and quality. A room in an appropriate hotel with fine outlook, if accompany with an undesirable food in the restaurant of the same hotel, undoubtedly will lose its value and desirability in a great extent (Ranjbarian, 2005). Tourism product and services consists of a wide range of different organizations and industries, including aviation companies, hotels, and restaurants, and for a tourist it is not possible to buy each service separately. To the same reason, some organizations under the title of touring agencies attempt to purchase of the elements such as transportation, residence, nutrition and the other services, and supply them to the tourists while combining them together as" one travel package".

So it results in saving time and money of the tourists. Also of the most important features of the organizations are their ability to create equilibrium between supply and demand of the products such as transportation and residence. Because touring agencies prevent from excess of supply by pre-buying of this services and they control imbalance in market of tourism products. Increasing the number of tourism agencies can lead to more competitive a market and consequently raising the quality of the services and decreasing their prices. Thus one way to develop tourism industry in a region is multiplicity of these organizations and agencies. In Iran the number of touring agencies are raising rapidly, so that, it has reached from 433, in 1996, to 2352, in 2010 (Iran cultural heritage organization), that shows high potential of absorption of tourist in Iran. 


\section{Tourism attractions}

Another important and main factor in tourism industry is tourism attractions. In fact, the main purpose of tourists from travelling to a place is visiting and enjoyment from its attractions. So, recognition and introducing the attractions to the people is very important for tourism development and boom. Generally, these tourism attractions include two groups of natural and handmade attractions. Natural attractions include outlooks, green space, mountain, waterfalls, beaches and wild life that people play new role to create these attractions. While handmade attractions are production of history, civilization and culture of nations and have been made by humans. Handmade attractions are divided to two kinds of old and modern.

Historically, old attractions have not been made for tourism use. Persepolis, Tchogha Zanbil, Bisotun, Pasargadae, Bam citadel, Takht-e Soleyman, Soltaniyeh dome, Meidan Emam Isfahan, Shushtar Historical Hydraulic System, Armenian Monastic Ensembles of Iran, Sheikh Safi al-din tomb and Tabriz Historic Bazaar Complex are from old attractions of Iran that have been made for military, religious, business purpose and some for life.

Persepolis is the name of one of the ancient cities of Iran that was capital of Achaemenid Kingdom dynasty for many years. Construction of this great building was started by great Darius (grandson of great Cyrus) in 515 B.C and continued by his successors so that has taken 120 years. According to professor Ernest Emil Herzfeld researches that was done in 1931. Persepolis was made for different reasons such as need to royal and majestic atmosphere and a symbol for Pars Empire, also having a place for special ceremonies like Norooz (New Year) and acceptance foreign guests. Based on discovered inscriptions in Persepolis, countless architects, artists, workers and women participated in making this great buildings that addition to wage, had also labor insurance benefits and maternity leave. Persepolis has been located $45 \mathrm{~km}$ from Shiraz city and registered in UNESCO at 1979.

Tchogha Zanbil is another historic attraction of Iran which is an ancient temple and has been built 3300 years ago. This buildings is in the south west of Iran and around the ancient city of Susa. Tchogha Zanbil is a local word which means basket shaped hill which come from the shape of building, because it is like an inverted basket. The purpose of constructing buildings was creation a place for invocation and implementation of religious ceremonies. Tchogha Zanbil has been hidden under ground for long centuries until was discovered by Roman Girshman who was from France about 60 years ago. These buildings registered in UNESCO at 1979.

Bisotun inscription which has remained from Achaemenid Dynasty period, has located near Kermanshah city and on the hillside of Bisotun Mountain. This mountain is one of the most important and the most famous historical documents which describes victory of great Darius in counter with rebels and capture of them. Length of this inscription is 6 meters and its width is 3 meters. In this inscription, Darius has brought up his right hand as a sign of thanksgiving and rebels with fastened hands have stranded tandem against Darius. A lancer and an archer are seen also behind Darius. Main writing of Bisotun inscription include introduction of Darius from himself tongue. His method in governance, his victories in 19 war, how establishment of peace and security in vast empire, warning about lying, defend the honesty and trustfulness and pray for country and people. Bisotun inscription is $8^{\text {th }}$ Iranian monument that registered in $30^{\text {th }}$ UNESCO meeting at 2006 in Lithuania.

Pasargadae is $5^{\text {th }}$ historical attractions in Iran that registered in UNESCO World Heritage in 2004. The ancient city of Pasargadae was the first capital of Achaemenid dynasty, which has been built by great Cyrus in600 B.C (before birth of Christ). Cyrus after the triumph over Medes, choosed the Pasargadae region as his capital and extended his empire. The most important monument in the Pasargadae complex is tomb of the great Cyrus. This building has been made from white limestone in 530 B.C. The buildings of tomb are in the middle of empire gardens and have been made from great stone some by 7 meters long. In the past it was conceived that the building related to the excellency prophet Solomon's mother, until in 1830 undergoing archeological investigations, the main identity of the building was recognize as the great Cyrus tomb. This complex is in 135 $\mathrm{km}$ to the north of Shiraz city in south west of Iran.

Bam citadel is the largest mud buildings in the world being in the vicinity of Bam town in Kerman province, south west of Iran. This building has been registered in the list of the UNESCO world Heritage too. Bam citadel was built in 2000 years ago, and includes two separate parts. The ruling section in the core of the citadel includes observation tower, water wells, and very big stable which are connected to the residence section through a gate. The residence section includes 400 house, mosque, Bazaar and school that some people were living there until 1850. Because Bam citadel is near by the Silk Road and international routes, always has been enjoyed of a high importance. Area of the citadel is nearly 20 hectares and its walls are 7 meter tall. 
Takht-e Soleyman is name of a large historical site near Takht-e Soleyman village in west of Iran. The length of this is 120 meters and its width is 80 meters and has been built around a natural lake. The lake water comes from the depth of 116 meters underground to the surface and flows to the surrounding lands. This water has large amounts of salt made it improper for drinking and irrigation. The most important monument of the complex is a big fire temple, which is believed that one was residence of the Zoroaster, ancient Iran messenger. The date of residence of human in this region backs to 3000 years ago, and one of most historically important sites that has registered with UNESCO world heritage as forth Iranian monument.

Soltaniyeh dome is the largest brick dome in the world, and the most magnificent Islamic building that well known from aspect of architecture in world. This building has an octagon shape that length of each side is 30 meters, and the blue colored dome with height of 49 meters has made on these sides in the construction. The construction of this dome was began about 7 centuries ago and took 9 years long. The Soltaniyeh dome ranking in bigness is the third in the world. Next to the Florence dome in Italy and the Aya-soufiyyeh dome in Turkey, and was registered with the UNESCO world Heritage Committee in 2005.

Meidan Emam Isfahan is a rectangular square in a length of 507 meters and a width at 158 meters in the city of Isfahan central Iran which is the biggest square in world next to the Tiananmen Square in China. Date of construct the square backs to 600 years ago. This square was used for national and religious rituals, and also for playing polo in the past. Surrounding the square there are 4 Bazaars and 200 shops which are places of manufacture and supplying handicrafts. Commercial, governmental and religious building and also the most ancient polo gate existing in the middle of the square are the most important architecture attractions of the square. This relic was registered with the UNESCO world Heritage in 1979.

Shushtar Historical Hydraulic System was built in 1500 years ago to use from water power in running industrial mill. In these large complex buildings of mills, great channels and tunnels for directing water flow are significant. In the years ago, to the reason of depending between economy and agriculture, rulers raised the level of agriculture and its proceed by develop of this complex. This complex that was registered with the UNESCO in 2009 is biggest industrial complex until the industrial revolution.

Armenian Monastic Ensembles is the name of a historical church located in north western Iran, has been reconstructed about 800 years ago while the accurate date of its construction is unknown. The church is burial place of the sacred Tad news, one of the Jesus Christ's disciples that arrived in Iran in 43 A.C (After birth of Christ) in order to conveying his message. This relic was registered with the UNESCO world Heritage in 2008.

Sheikh Safi al-din tomb is burial place of the well known Gnostic Sheikh Safi al-din, built in 600 years ago. The monument has achieved world reputation for its beautiful tiring and tore. Tabriz Historic Bazaar Complex having 5500 shops and stores, and 40 type of job is the biggest Bazaar covered by ceiling in world. These two relics located in north western Iran, and were registered with UNESCO in the summer of 2010.

Beside the old tourism attractions, are the modern ones that main objective of making them is attracting of the tourists. Most of these attractions have been made in accordance to the current needs of the tourists. Disney Lands, recreational islands, art and cultural festivals, national parks, and zoos include the modern world's attractions that attract many tourists from different areas of the world. Also one of favorite activities of tourists is shopping, to the same reason trade and buying centers are accounted from tourism attractions. Particularly if this centers be specialty ones, like the carpet market, car market or gold and jewelry market. Such markets have especially appealing and their products are supplied at various and fair prices, because of the competition.

Natural attractions are also very important, and always create especial competitive advantages for the own countries. As these attractions cannot be easily developed, and it requires thousands of years, so countries with the natural attractions, by properly exploitation from them, must use their benefits in maximum level. Unfortunately many tourists are not familiar with the natural attractions. In fact, most often people are familiar with the historical attractions, due to studying the history, while natural attractions are generally unknown, thus it is the task of the responsible persons to draw tourists attention to them by promoting and introducing these attractions to different communities of the world.

Iran is also a rich country in regard to its natural attractions. Of these beautiful and surprising attractions we can refer to the Ali-Sadr cave in Hamadan town. The city of Hamadan itself is an ancient town and one of important tourist center. Hamadan once was the primary capital of the Medes, and its old name is "Hegmataneh". Medes were one of the Aryan tribes arrived in Iran about 3000 years ago and lived in this land. Ali-Sadr cave in Hamadan is the largest world's water cave, and one of the exceptional attractions of Iran and the world. The cave is located at the altitude of 1980 meters from sea level, and the depth of water in cave is 14 meters. The water of the cave is of the cold water categories (12 c. degrees centigrade), without a particular odor and taste. Its color is 
slight blue and very transparent, so that even at points by 5 meters depth, its bottom is visible well. Also due to lime salts in the water, it is undrinkable and without any type of live organism. The air inside the cave is light, neat, and without dost. Ali-Sadr cave has a very long record and the stones inside the cave date back to about 200 years ago. Villager's, who dwelling around in old times, has found it and used its water. Until a 14 person group from the Hamadan mountaineers board, attempted to visit and exploit it on $5^{\text {th }}$ October 1963, they could travel inside the cave some distance using primitive equipments, such as lanterns, and rubber tubes. In 1967 by broadcasting the news of the discovery of this astonishing and endless cave in the national media, investigators, mountaineers and individual who were interested in the natural relics rushed hereto. Since that times attempts has been made inside for easement of the tourists visit, and welfare, increasing the path of sailing inside, and also some tracks in drought, bringing new and novel spectacles at the sight of keen tourists. At present about $14 \mathrm{~km}$ from the cave has been discovered which just $4 \mathrm{~km}$ visiting distance is now possible. In the same time experts believed that the real length of the cave is still very longer. The Ali-Sadr cave having a fixed climate $(25 \mathrm{c})$ holds as one of the tourism poles.

\section{Background of research}

So far many researchers have been done about tourism industry. Dieke (2003) analyzed the effect of tourism industry on economic growth in African countries. The results of this study indicated that successful development of tourism industry based on common planning of countries and local cooperating in Africa, cause well to economic growth in this continent.

Perry and Riege (2000) studied the extent of success of marketing strategies in attraction of more tourists in Australia. The results indicated that market segmentation can effectively improve tourism goals.

Zhang (2004) studied the effect of access of china to the WTO (world trade organization) on tourism industry. The results of study showed that with joining of china to the WTO, its tourism industry become more competitive which increases the number of tourism agencies and improved the tourism services quality.

Joliffe and Fransworth (2003) analyzed the challenges of human resource management in tourism industry. The result of studies indicated that the tourism industry sometimes during the year faces with lack or surplus of labor force because of being seasonal, which can overcome this problem through using seasonal employment mode.

Hsu and Huang (2009) studied the motives of travels. The results of this study show that the main motives of people for travelling come from their internal psychological needs and tourism managers should design their product based on these needs.

Leung and Wong (2004) studied the effect of internet on tourism agencies. The result of studies indicated that most of tourists receive their major information directly from internet, but yet the travel and tour agency is the main means between tourists and tourism goods.

\section{Methodology}

The type of this paper is descriptive-cognition and the related information for this scope have been collected by using library resources such as scientific books and journals, moreover for collecting necessary data in order to accept or reject the hypothesis, a questionnaire designed by researchers has been used, mentioned questionnaire has four selective choices and their answers are varied between the most and the least. Furthermore the scope of research from the view point of subject is investigating effective factors on tourism industry in Iran. The time that this research has been done was July 2010 and the statistical society of research includes fifty experienced managers from tourism agencies in Isfahan province and random sampling method was used in this research.

Independent variables of research include advertisement and informing people, tourist's safety and security, reducing tourism expense, increasing welfare services and its quality, increasing foreign investment and expanding foreign relation and dependent variable is effective factors on tourism industry. In this study for summarizing extractive data to accept or reject the hypotheses of research used SPSS software and presumption statistics method (like $\mathrm{T}$ as single sample) have been used. Which $\mathrm{T}$ refer to statistic data, in case the SIG (meaningful level) is less than 0.05 hypothesis $\mathrm{H} 0$ will be rejected and hypothesis $\mathrm{H} 1$ will be accepted as well as DF shows the degree of freedom.

H0: $\mathrm{m} \leq 0.05$

$\mathrm{H} 1: \mathrm{m} \geq 0.05$

\section{Data analysis}

In this section by using given statistical method, and collected information and extractive results from questionnaires the research hypotheses have been tasted. 


\subsection{First hypothesis}

Informing and international advertising are effective on development of tourism industry.

H0: Informing and international advertising are not effective on development of tourism industry.

H1: Informing and international advertising are effective on development of tourism industry (Table 3).

The analysis of finding related to the first research hypothesis in the error level of 0.05 and reliability level of 0.95 shows that the significant level of 0.0008 is less than 0.05 , so the hypothesis $\mathrm{H} 0$ will be rejected and the hypothesis H1will are accepted. Informing and presented local and international propaganda in order to draw natural facilities and talents, various tourism attractive and introduce the culture, history and civilization of a country are effective in development of tourism industry,but despite the importance of this issue never been considered by responsible persons.

Using modern and suitable methods in propaganda in order to introduce tourism attractive of Iran, participating in popular touring exhibitions around of the world, activating culture-houses in different countries as well as using of television and internet programs, all are positive steps toward tourism industry development

\subsection{Second hypothesis}

Creating comfort and security for tourists are effective on development of tourism industry.

H0: Creating comfort and security for tourists are not effective on development of tourism industry.

H1: Creating comfort and security for tourists are effective on development of tourism industry (Table 4).

Regarding to the second hypothesis, base on analysis of data from response of statistical society, our findings indicated that the significant level of 0.0054 is less than 0.05 , so the hypothesis $\mathrm{H} 0$ will be rejected and the hypothesis H1will be accepted. So, one of the most important elements that is cause of weakness in tourism industry is lacking of security and tranquility. In other words, increasing of insecurity in financial and life aspects create decreasing tendency of tourists to visit, so those who responsible must pay more attention to this issue.

\subsection{Third hypothesis}

Increasing welfare services and improves its quality are effective on development of tourism industry.

H0: Increasing welfare services and improves its quality are not effective on development of tourism industry.

H1: Increasing welfare services and improves its quality are effective on development of tourism industry (Table 5).

Analysis of finding data related to the third research hypothesis in error level of 0.05 and reliability level of 0.95 indicates that the significant level of 0.0002 is less than 0.05 ; so, it proves the importance of welfare services and its infrastructures in tourism industry. The results of questionnaire analysis also shows statistical society of the study who are experts of this industry also accepted these services are not in a desirable condition and in order to attract more tourist Iran must increase the variety and quality of welfare services .

\subsection{Fourth hypothesis}

Decreasing the costs of tourism is effective on development of tourism industry.

H0: Decreasing the costs of tourism is not effective on development of tourism industry.

H1: Decreasing the costs of tourism is effective on development of tourism industry (Table 6).

Tourists expenditure is always important for a tourist, he or she try to get more enjoy from the trip and pay lowest cost. The analysis of data regarding the forth hypothesis of research in error level of 0.05 and reliability level of 0.95 with significant level of .0072 which is less than 0.05 proved that decreasing the cost of tourism is effective in attracting more tourist and development of this industry. One of the advantages of Iran in competition with other countries in order to attract tourists is the cost of tourism which is very low because the value of money in Iran is very low compare with many countries. Moreover, decreasing traveling costs, makes enable people with low incomes also travel. Iran must make more competitive its tourism industry through decreasing of prices and diversified tourism products.

\subsection{Fifth hypothesis}

Increasing foreign investment is effective on development of tourism industry.

H0: Increasing foreign investment is not effective on development of tourism industry. 
H1: Increasing foreign investment is effective on development of tourism industry (Table 7).

The weaknesses of Iran's tourism industry are lack of competitive ability and lack of interest for foreign investment in this sector. Analysis of fifth hypothesis in the error level of 0.05 and reliability level of 0.95 with the significant level of .0046 which is less than 0.05 has proved this case well. Foreign investing increase competition between tourist agencies to provide better services and also creates job opportunities which are the best help for Iran's economic condition.

\subsection{Sixth hypothesis}

Expanding foreign relation is effective on development of tourism industry.

$\mathrm{H} 0$ : Expanding foreign relation is not effective on development of tourism industry.

H1: Expanding foreign relation is effective on development of tourism industry (Table 8).

As the significant level of 0.0001 is less than 0.05 , so the analysis of responses regarding this hypothesis indicates that foreign policy has an important role in development of tourism industry. Findings of this hypothesis also showed one of the reasons that the tourism industry in Iran could not grow as well as possible was the mentioned problem.

\section{Conclusion}

Tourism industry is the biggest and the most interesting industry in the world and base on prediction of WTO (world tourism organization) it will be the first industry in the world by 2020. Nowadays tourism industry with creating 330 million jobs around of the world has allocated $12 \%$ of total world investment to itself. This is why many of countries are considering this dynamic industry as the main source of, revenue, job creation, private sector growth and development of economic infrastructure, especially developing countries that from the aspect of production and technology have no competition power with other developed countries, pay more attention to tourism industry. Iran also must give more attention to it in order to emancipate its relied economy on oil as well as increase of foreign revenue and develop its infrastructures, and through using new knowledge of the world and advanced technologies develop its tourism industry.

Iran should identify its weaknesses in the first step and in order to remove these problems do effective action. Hypothesis 1,3,6 base on responses from statistical society of research showed, the major deficiencies of Iran in tourism industry are regarding foreign policies, quality of welfare services and international advertising. Therefore it is really necessary for the government and those who are responsible about this industry to give more attention to above factors. The second, fourth and fifth hypothesis also showed the important role of internal security, prices of tourism products and foreign investment in development of tourism industry. In general, based on the finding of this research Iran can develop its tourism industry through increased international advertisement, expand foreign relation, improve the quality of welfare services, decrease tourism products prices as much as possible and encourage foreign investors to invest in this industry.

\section{References}

Costa, Jorge. (1995). International Perspectives on Travel and Tourism Development. International Journal of Contemporary Hospitality Management, Vol.7, No.7, pp.10-19. http://dx.doi.org/10.1108/09596119510101886

Dieke, Peter. (2003). Tourism in Africa's Economic Development: Policy Implications. Management Decision, Vol.41, No. 3, pp287-295. http://dx.doi.org/10.1108/00251740310469468

Dimitrios, Buhalis, \& Laws, Eric. (2001). Tourism Distribution Channels. Continuum London and New York.

Dunbar, Ian.K. \& McDonald, Malcolm. Market Segmentation: a step-by-step approach to creating profitable market segments. Palgrave Macmillan.

Dwyer, Larry \& Forsyth, Peter. (1997). Measuring the Benefits and yield from foreign tourism. International Journal of Social Economics, Vol. 24, No.1/2/3, pp.223-236.

Eccles, Gavin \& Costa, Jorge. (1996). Perspectives on Tourism Development. International Journal of Contemporary Hospitality Management, Vol.8, No. 7, pp.44-51. http://dx.doi.org/10.1108/09596119610152041

Faulkner, Bill., Moscardo, Gianna. \& Laws, Eric. (2001). Tourism in the 21 Century: Lessons from Experience. Continuum London and New York.

Gharanejad, Hassan. (2007). Introduction to Tourism Development and Hospitality. Azad University of Najaf Abad. 
Hu, Clarck. \& F.William. (1996). Diverse Development in Travel and Tourism Marketing: a Thematic Approach. International Journal of Contemporary Hospitality Management, Vol. 8, No. 7, pp.33-43. http://dx.doi.org/10.1108/09596119610152032

Ingram, Haydn. (1995). Hospitality and Tourism: International Industry Experiencing Common Problems. International Journal of Contemporary Hospitality Management, Vol. 7, No. 7, pp.44-54. http://dx.doi.org/10.1108/09596119510101930

Jennings, Gayle. (2001). Tourism Research. John Wiley and sons Australia, Ltd.

Jolliffe, Lee \& Fransworth, Regena. (2003). Seasonality in Tourism Employment: Human Resource Challenges. International Journal of Contemporary Hospitality Management, Vol. 15, No. 6, pp.312-316. http://dx.doi.org/10.1108/09596110310488140

Kamata, Hiromi., Misui,Yuki., \& Yamauchi,Hirotaka. (2010). How to attract more Tourists. Tourism Review, Vol. 65, No. 2, pp.28-40. http://dx.doi.org/10.1108/16605371011061606

Law, Rob., Leung, Kenith., \& Wong,James. (2004). The Impact of Internet on the travel agencies. International Journal of Contemporary Hospitality Management, Vol. 16, No. 2, pp.100-107. http://dx.doi.org/10.1108/09596110410519982

Lumsdon, Les. (1997). Tourism Marketing. International Thomson Business Press.

Mazloumi, Nader. (2007). Risk Management. Journal of accounting, Vol. 8, No. 2, pp.10-14.

Mowforth, Martin \& Munt, Ian. (2003). Tourism and Sustainability: Development and New Tourism in the Third World. Routledge Taylor and Francis Group, Second Edition.

Oxford University Press. (1998). Oxford Advanced Learner's Dictionary, pp.1036.

Pine, Ray \& Mckercher, Bob. (2004). The Impact of SARS on Hong Kong's Tourism industry. International Journal of Contemporary Hospitality Management, Vol. 16, No. 2, pp.139-143. http://dx.doi.org/10.1108/09596110410520034

Ranjbarian, Bahram \& Zahedi, Mohammad. (2005). An Introduction to Tourism. University of Isfahan.

Riege, Andreasm \& Perry, Chad. (2000). National Marketing Strategies in International Travel and Tourism. European Journal of Marketing, Vol. 34, No. 11/12, pp.1290-1305. http://dx.doi.org/10.1108/03090560010348452

Rita, Paulo. (2000). Tourism in the European Union. International Journal of Contemporary Hospitality Management, Vol. 12, No. 7, pp.434-436. http://dx.doi.org/10.1108/09596110010347374

Uzama, Austin. (2009). Marketing Japan's Travel and Tourism industry to International Tourists. International Journal of Contemporary Hospitality Management, Vol. 21, No. 3, pp.356-365. http://dx.doi.org/10.1108/09596110910948341

Vospitannik, Natalia \& Little John, David. (1997). Environments, Tourism and Tour operators: 1985-1995 in Central and Eastern Europe. International Journal of Contemporary Hospitality Management, Vol. 9, No. 5/6, pp.209-214. http://dx.doi.org/10.1108/09596119710172589

Walle, Alf.H. (1996). The USA Encourages International Tourism. European Business Review, Vol. 96, No. 3, pp.50-56. http://dx.doi.org/10.1108/09555349610116771

Zhang, Guangrui, Pine, Ray \& Zhang, Hanqin Qiu. (2000). China International Tourism Development: Present and Future. International Journal of Contemporary Hospitality Management, Vol. 12, No. 5, pp.282-290. http://dx.doi.org/10.1108/09596110010339634

Zhang, Hanqin Qiu \& Morrison, Alison. (2007). How Can Small to medium sized travel agents Stay Competitive in China's travel service sector? International Journal of Contemporary Hospitality Management, Vol. 19, No. 4, pp.275-285. http://dx.doi.org/10.1108/09596110710747616

Zhang, Hanqin Qiu, (2004). Accession to the World Trade Organization: Challenges for China's travel service industry. International Journal of Contemporary Hospitality Management, Vol. 16, No. 6, pp.369-372. http://dx.doi.org/10.1108/09596110410550815

[Online] Available: http://en.wikipedia.org/wiki/List_of_countries_by_intentional_homicide_rate 
[Online]

Available: http://pub.worldtourism.org:81/epages/Store.sf/?ObjectPath=/Shops/Infoshop/Products/1487/SubProducts/14871

[Online]

Available: http://www.bmwfj.gv.at/Tourismus/TourismusInOesterreich/Documents/UNWTO\%20Highlights\%202010.pdf [Online] Available: http://www.noahhite.org/pdf_files/webpages/murder_rates_countries.pdf [Online] Available: http://www.unwto.org/facts/eng/pdf/highlights/UNWTO_Highlights09_en_LR.pdf [Online] Available: http://www.unwto.org/facts/eng/pdf/highlights/UNWTO_Highlights09_en_HR.pdf [Online] Available: www.Unescoworldheritagesites.com/iran-unesco-world-heritage-sites.htm [Online] Available: www.unwto.org/statistics/publications/publications.htm

Table 1. Tourism revenue of some countries

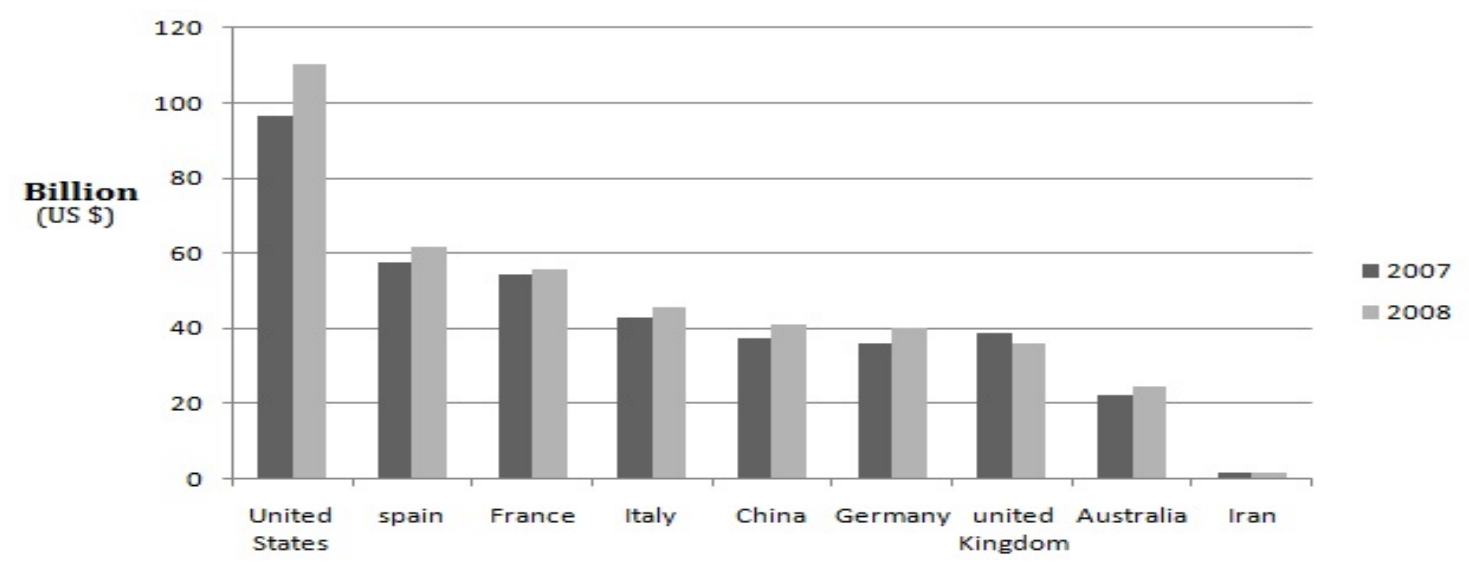

Source: unwto, 2009

Table 2. International homicide and crime rates by region of the world

\begin{tabular}{|l|l|l|}
\hline $\begin{array}{l}\text { International homicide and crime rates } \\
\text { per } \begin{array}{l}\text { 100,000 population by region and } \\
\text { subregion,2004 }\end{array}\end{array}$ & $\begin{array}{l}\text { Percentage of tourist } \\
\text { arrivals,2009 }\end{array}$ \\
\hline Southern Africa & 37.3 & $\% 3.1$ \\
\hline Central America & 29.3 & $\% 0.9$ \\
\hline South America & 25.9 & $\% 2.2$ \\
\hline Africa & 20 & $\% 4.9$ \\
\hline Caribbean & 18.1 & $\% 2.1$ \\
\hline North Africa & 7.6 & $\% 1.8$ \\
\hline North America & 6.5 & $\% 10.5$ \\
\hline South -east Europe & 3.2 & $\% 19.4$ \\
\hline East, north-east Asia & 2.8 & $\% 18.1$ \\
\hline West and central Europe & 1.5 & $\% 28$ \\
\hline
\end{tabular}

Source: unwto, 2009 
Table 3. First hypothesis test in the error level of 0.05 (reliability level of 0.95 )

\begin{tabular}{|c|c|c|c|}
\hline $\mathrm{T}$ & AVERAGE & DF & SIG \\
\hline 1.843 & 3.40 & 50 & 0.0008 \\
\hline
\end{tabular}

Table 4. Second hypothesis test in the error level of 0.05 (reliability level of 0.95)

\begin{tabular}{|c|c|c|c|}
\hline $\mathrm{T}$ & AVERAGE & DF & SIG \\
\hline 2.981 & 3.85 & 50 & 0.0054 \\
\hline
\end{tabular}

Table 5. Third hypothesis test in the error level of 0.05 (reliability level of 0.95 )

\begin{tabular}{|c|c|c|c|}
\hline $\mathrm{T}$ & AVERAGE & DF & SIG \\
\hline 0.695 & 3.25 & 50 & 0.0002 \\
\hline
\end{tabular}

Table 6. Fourth hypothesis test in the error level of 0.05 (reliability level of 0.95 )

\begin{tabular}{|c|c|c|c|}
\hline $\mathrm{T}$ & AVERAGE & DF & SIG \\
\hline 3.12 & 3.98 & 50 & 0.0072 \\
\hline
\end{tabular}

Table 7. Fifth hypothesis test in the error level of 0.05 (reliability level of 0.95 )

\begin{tabular}{|l|c|c|c|}
\hline $\mathrm{T}$ & AVERAGE & DF & SIG \\
\hline 2.19 & 3.76 & 50 & 0.0046 \\
\hline
\end{tabular}

Table 8. Sixth hypothesis test in the error level of 0.05(reliability level of 0.95)

\begin{tabular}{|c|c|c|c|}
\hline $\mathrm{T}$ & AVERAGE & DF & SIG \\
\hline 1.512 & 3.21 & 50 & 0.0001 \\
\hline
\end{tabular}
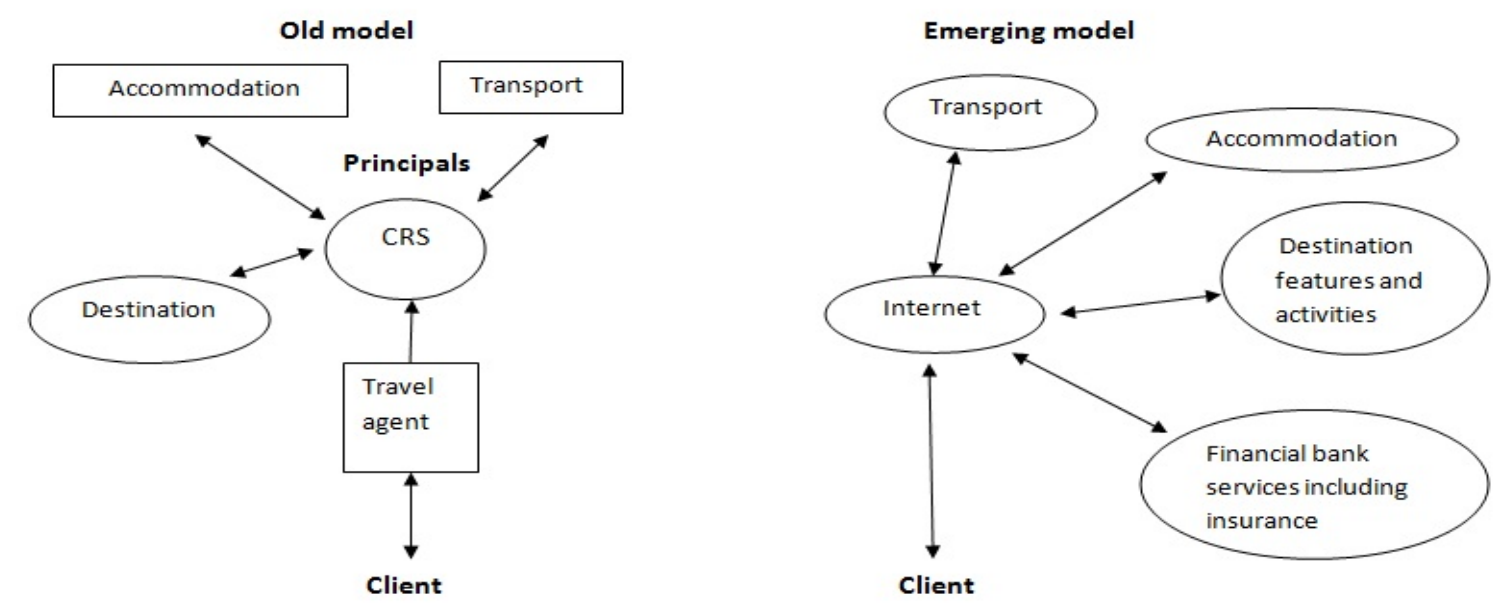

Figure 1. Compare old and modern model of information channel in tourism industry

Source: Dimitrios and Laws, 2002 